Int. J. Electrochem. Sci., 15 (2020) 10509 - 10523

International Journal of

ELECTROCHEMICAL

SCIENCE

WWW.electrochemsci.org

\title{
Effect of carbon nanodots supported palladium-based electrocatalysts towards oxygen reduction reaction in an alkaline medium
}

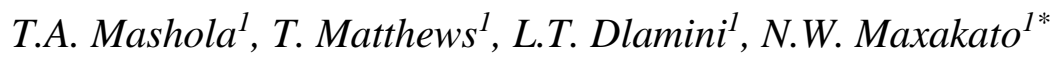 \\ Department of Chemical Sciences, University of Johannesburg, Doornfontein, 2028, South Africa. \\ *E-mail: nmaxakato@uj.ac.za
}

doi: $10.20964 / 2020.10 .44$

Received: 25 May 2020 / Accepted: 10 July 2020 / Published: 31 August 2020

Carbon nanodots (CNDs) have been synthesised using a simple and cheap pyrolysis method. The $\mathrm{Pd} / \mathrm{CNDs}$ electrocatalyst was synthesised by the in-situ reduction method. The calculated particle sizes were found to be $6.0 \mathrm{~nm}$ and $0.974 \mathrm{~nm}$ for CNDs and Pd nanoparticles, respectively. The reaction kinetics of the $\mathrm{Pd} / \mathrm{CNDs}$ was found to have an onset potential of $-0.111 \mathrm{~V}$, which is $0.052 \mathrm{~V}$ lower than that of $\mathrm{Pd} / \mathrm{C}$. CNDs are good electrocatalysts support, as supported by durability and stability studies. The electrocatalyst showed improved durability and stability when CNDs were used as the support material for the Pd nanoparticles.

Keywords: carbon nanodots, electro-catalysis, oxygen reduction reaction, electrode, fuel cells

\section{$\underline{\text { FULL TEXT }}$}

(C) 2020. The Authors. Published by ESG (www.electrochemsci.org). This article is an open access article distributed under the terms and conditions of the Creative Commons Attribution licence (http://creativecommons.org/licenses/by/4.0/). 